\title{
IMPLEMENTASI KURIKULUM 2013 REVISI PADA PROGRAM STUDI TEKNIK KENDARAAN RINGAN BERDASARKAN PERSEPSI GURU DAN SISWA DI SMK
}

\author{
Heri Nasrul Mustajib \\ Amat Mukhadis \\ Eko Edi Purwanto
}

\begin{abstract}
Abstrak: Tujuan penelitian adalah untuk mendeskripsikan implementasi kurikulum 2013 revisi berdasarkan persepsi guru dan siswa. Penelitian ini memaparkan Implementasi Kurikulum 2013 Revisi dalam proses pembelajaran. Jenis penelitian adalah penelitian deskriptif dengan sampel responden guru dan siswa pada mata pelajaran Teknolog Dasar Otomotif. Variabel penelitian adalah Implementasi Kurikulum 2013 Revisi. Teknik pengumpulan data menggunakan kuesioner. Validitas instrumen penelitian berdasarkan validitas isi, kontruk, dan konkuren. Uji reliabilitas menggunakan Cronbach's Alpha. Teknik analisis menggunakan statistik deskriptif kuantitatif. Hasil penelitian menunjukkan bahwa persepsi guru diperoleh rerata 144,41 dipersepsikan baik, persepsi siswa diperoleh rerata pada kegiatan pendahuluan 19,93, kegiatan pelaksanaan 44,25, kegiatan penutup 12,62 dipersepsikan baik, hasil analisis sub bab perencanaan $54,00 \%$, pelaksanaan $65,00 \%$, dan evaluasi $71,00 \%$ menyatakan implementasi Kurikulum 2013 revisi sepenuhnya terlaksana.
\end{abstract}

Kata-kata Kunci: kurikulum 2013 revisi, persepsi guru, persepsi siswa

\begin{abstract}
The Implementation of Revised 2013 Curriculum at The Light Vehicle Engineering Study Program Based on Teacher and Student Perception in SMK. This research aims to explore the implementation of Revised 2013 Curriculum at SMK in Blitar. The research was a descriptive research with the sample of the respondents, namely teachers and students on the subjects of Basic Automotive Technology. The research variable was the Implementation of Revised 2013 Curriculum. Data were collected using questionnaires. The validity of research instruments was based on the validity of contents, constructs, and concurrent. The reliability test used Cronbach's Alpha. The analysis technique used a quantitative descriptive statistics. The results showed that the perception of teachers obtained a mean of 144.41 and perceived as good, the students' perceptions average score in preliminary activities was 19,93, the implementation activities was 44.25, the closing activities was 12.62 and there were perceived as good, the analysis results of the planning subproject was $54.00 \%$, the implementation subproject was $65.00 \%$, and the evaluation subproject was $71.00 \%$ and stated the implementation of Revised 2013 curriculum as fully implemented.
\end{abstract}

Keywords: revised 2013 curriculum, teacher perceptions, student perceptions masalahan ketika Kurikulum 2013 per-

Heri Nasrul Mustajib adalah Mahasiswa Jurusan Teknik Mesin Universitas Negeri Malang. Email: h3574dirgantara@gmail.com. Amat Mukhadis dan Eko Edi Purwanto adalah Dosen Jurusan Teknik Mesin Universitas Negeri Malang. Alamat Kampus: Jl. Semarang No. 5 Malang 65145 
tama kali dilaksanakan secara nasional pada tahun 2014. Baswedan (2016:4-5) berpendapat bahwa permasalahan yang paling bisa dirasakan adalah ketergesaan. $\mathrm{Hal}$ itu berakibat buku pegangan Kurikulum 2013 tidak dikerjakan dengan benar dan banyak sekali yang terlewatkan. Dari permasalahan tersebut perlu ditata ulang dalam pelaksanaannya serta dilakukan secara bertahap dan tidak sekaligus. Hal ini sesuai dengan PP No. 32 Tahun 2013, Kurikulum 2013 diterapkan secara bertahap selama tujuh tahun sejak aturan disahkan. Selain itu, merujuk dari majalah Dikbud edisi III 2016 permasalahan Kurikulum 2013 antara lain: (1) kompleksitas pembelajaran dan penilaian pada Sikap Spiritual dan Sikap Sosial; (2) ketidakselarasan antara KI-KD dengan silabus dan buku; (3) penerapan proses berpikir 5M sebagai metode pembelajaran yang bersifat prosedural dan mekanistik; (4) pembatasan kemampuan siswa melalui pemenggalan taksonomi proses berpikir antar jenjang. Permasalahan tersebut untuk selanjutnya diadakan pembenahan pada Kurikulum 2013 Revisi.

Guru adalah pendidik profesional dengan tugas utama mendidik, mengajar, membimbing, mengarahkan, melatih, menilai dan mengevaluasi peserta didik pada pendidikan anak usia dini jalur pendidikan formal, pendidikan dasar, dan pendidikan menengah (Amanto, dkk. 2013). Hasil penelitian oleh Waybin (2014:103) bahwa, “... pelaksanaan pembelajaran menggunakan pendekatan scientific approach, project based learning, discovery learning masih sulit untuk diterapkan ...". Hasil penelitian oleh (Untari, dkk. 2015) menunjukkan bahwa variabel pemahaman guru Program Keahlian Teknik Komputer dan Informatika di SMK Malang Raya dalam kategori rendah dengan persentase pencapaian sebesar $54,83 \%$. Data penelitian dari Leonokto (2016:48), menemukan bahwa “... guru belum mengerti dengan konsep fa- silitator akibatnya guru hanya diam saja di kelas dan membiarkan siswanya untuk belajar sendiri tanpa ada bimbingan dari guru ...". Perlu disadari guru merupakan faktor penting yang sangat besar pengaruhnya dan menentukan keberhasilan peserta didik dalam belajar. Roche (2017) berpendapat, bahwa "Education, like any project, is constrained by the aims of its designers". Jadi, guru diharapkan mampu memfasiltasi peserta didik dalam proses pembelajaran sesuai dengan Kurikulum 2013 Revisi. (Amanto, dkk. 2013) menegaskan bahwa guru akan membentuk watak dan jiwa bangsa, baik buruknya bangsa ini sangat tergantung kepada guru. Hal ini membuktikan peran guru sangat menentukan kepribadian bangsa yang berkarakter.

Timbul permasalahan terkait dimensi karakter. Pendidikan kejuruan juga harus diimbangi dengan pendidikan karakter. Dalam praktiknya guru harus mampu menerapkan antara nilai karakter dengan ilmu pengetahuan agar seimbang. Hasil Peneltian oleh Molikavia, dkk. (2015) mengungkapkan hubungan antara kecakapan sosial dengan keberhasilan dalam prakerin merupakan hubungan yang positif dan signifikan. Permasalahan utama di dalam lingkup konsep sumber daya manusia umumnya hanya pada kompetensi seseorang dan permasalahan karakter kurang mendapat perhatian (Tuwoso, 2013). Padahal dunia kerja dan industri tidak hanya mementingkan kompetensi teknikal saja tetapi dimensi karakter yang dimiliki seseorang lebih penting. (Sasmito, dkk. 2015) menyimpulkan, “... semakin tinggi penguasaan mata pelajaran produktif akan memberikan kontribusi positif terhadap perubahan kesiapan siswa untuk bekerja di DU/DI namun tidak signifikan". Hal tersebut perlu adanya penerapan pendidikan karakter di setiap jenjang pendidikan termasuk sekolah kejuruan. Selain itu diharapkan dengan nilai-nilai karakter yang diterapkan pada 
sekolah kejuruan, peserta didik mampu bersaing di era global, beretika dan bermoral, serta mampu berinteraksi dengan masyarakat.

Sasaran penenlitian ini ditujukan kepada SMK wilayah kota dan kabupaten Blitar. SMK yang diteliti merupakan sekolah yang ditunjuk oleh Dirjen Dikdasmen untuk melaksanakan Kurikulum 2013 Revisi. Berdasarkan SK tentang penetapan satuan pendidikan pelaksana kurikulum 2013 revisi, maka SMK yang ditunjuk Dirjen Dikdasmen melaksanakan kurikulum 2013 Revisi. Kegunaan praktis dari penelitian ini, yaitu bagi guru, sekolah, dan pemerintah. Pertama, bagi guru. Hasil penelitian diharapkan dapat menjadi bahan masukan agar dapat mengoptimalkan kinerja dalam kegiatan mengajar. Khususnya pada mata pelajaran Teknologi Dasar Otomotif dalam mendampingi dan memfasilitasi peserta didik. Selain itu, dapat menjadi motivasi guru untuk meningkatkan keprofesionalan dan inovasi dalam proses belajar. Kedua, bagi sekolah. Pembanding perkembangan sekolah dalam mengimplementasikan Kurikulum 2013 Revisi yang selanjutnya dapat menjadi bahan evaluasi sekolah. Hasil penelitian ini sekaligus dapat menjadi bahan rujukan dalam memfasilitasi pengembangan Implementasi Kurikulum 2013 Revisi. Ketiga, bagi pemerintah. Hasil penelitian ini dapat menjadi bahan kajian tentang Implementasi Kurikulum 2013 Revisi di lapangan. Selain itu, diharapkan mampu memberikan perbandingan dan wacana terhadap pendidikan untuk mendukung peningkatan mutu pendidikan.

\section{METODE}

Penelitian kuantitatif ini menggunakan rancangan penelitian deskriptif (descriptive research) melalui pendekatan induktif. Menurut Mukhadis (2016: 220) bahwa, "penelitian deskriptif bertu- juan untuk mengungkapkan dan mendeskripsikan (memaparkan), memetakan, atau mencandra suatu peristiwa yang $u r$ gen terjadi pada masa kini ... berdasarkan data empiris secara utuh dalam suatu objek kajian ...". Jadi penelitian deskriptif bertujuan untuk memaparkan karakteristik suatu keadaan tertentu apa adanya tanpa ada perubahan dari sifat asalnya. Responden penelitian di dalam pelaksanaan penelitian adalah guru dan siswa di SMK Kabupaten dan Kota Blitar. Jumlah SMK ada 10 SMK dengan rincian 5 SMK wilayah Kabupaten dan 5 SMK wilayah Kota. Jumlah responden penelitian ini adalah 17 guru pengajar mata pelajaran Teknologi Dasar Otomotif (TDO) dan 10 kelas pada siswa kelas X TKR dengan total 224 siswa.

Proses analisis data dimulai dengan menelaah seluruh data yang diperoleh. Penelitian ini mengguanakan analisis data teknik statistik deskriptif. Teknik statistik deskriptif sebagai alat analisis dipilih dan digunakan apabila hasil analisis statistik hanya bertujuan untuk memerikan data (sensus ataupun sampel) terhadap suatu subjek/objek bidang yang diteliti (Mukhadis, 2017:332). Pemilihan teknik analisis statistik deskriptif pada analisis data berdasarkan data hasil penelitian bersifat sampel. Tujuan dari penelitian adalah meneliti sampel yang bersangkutan dan bukan mewakili populasi tertentu. Dasar pertimbangan lain dalam pemilihan teknik analisis statistik deskriptif dari jumlah dan sifat variabel. Variabel dalam penelitian ini bersifat univarite maka menggunakan teknik analisis statistik deskriptif.

\section{HASIL}

Persepsi guru terhadap implementasi kurikulum 2013 revisi dapat dijelaskna sebagai berikut. Data hasil penelitian menunjukkan bahwa persepsi guru terhadap Implementasi Kurikulum 2013 Revisi Bidang Keahlian TKR mata pelajaran 
TDO di SMK diperoleh rerata (mean) sebesar 144,411 terletak pada kelas interval 49-196 dengan kategori baik. Jadi dapat disimpulkan bahwa persepsi guru terhadap Implementasi Kurikulum 2013 Revisi Bidang Keahlian TKR mata pelajaran TDO di SMK Blitar berada pada taraf terlaksana dengan baik.

Pada hasil analisis penelitian menunjukkan bahwa mayoritas dari 17 guru memiliki persepsi bahwa Implementasi $\mathrm{Ku}$ rikulum 2013 Revisi mayoritas sudah terlaksana dengan baik bahkan ada 2 guru yang memiliki persepsi sangat baik dan ada 1 guru yang memiliki persepsi kurang baik bahkan ada 1 guru juga yang memiliki persepsi bahwa Implementasi Kurikulum 2013 Revisi tidak terlaksana.

Persepsi siswa terhadap implementasi kurikulum 2013 revisi per sepsi siswa terhadap kegiatan pendahuluan dapat dijelaskan sebagai berikut. Data hasil penelitian menunjukkan bahwa Persepsi Siswa terhadap Implementasi Kurikulum 2013 Revisi Kegiatan Pendahuluan pada kegiatan pendahuluan diperoleh rerata (mean) sebesar 19,93 terletak pada kelas interval 11-24. Untuk mengetahui kecenderungan skor variabel Persepsi Siswa SMK terhadap Implementasi Kurikulum 2013 Revisi Kegiatan Pendahuluan dilakukan dengan hitungan pembagian nilai maksimum-nilai minimum kemudian dibagi 4 kriteria. Disana menunjukkan bahwa 244 siswa sebanyak 13 siswa memiliki persepsi bahwa pelaksanaan Kurikulum 2013 Revisi terlaksana kurang baik karena dianggap beberapa ada yang masih sama dengan sebelumnya. Selanjutnya sebanyak 113 siswa $(46,00 \%)$ memiliki persepsi bahwa pelaksanaan Kurikulum 2013 Revisi Terlaksana baik dan sebanyak 118 siswa $(48,00 \%)$ memiliki persepsi bahwa pelaksanaan kurikulum 2013 revisi terlaksana sangat baik.

Pada hasil analisis ditemukan nilai rerata (mean) sebesar 19,92 ada di ren- tangan 16-20 maka dikatakan bahwa kecenderungan kegiatan pembelajaran di bagian pendahuluan oleh siswa dipersepsikan Terlaksana baik.

Persepsi siswa SMK terhadap kegiatan inti dapat dijelaskan sebagai berikut. Data hasil penelitian menunjukkan bahwa Persepsi Siswa terhadap Implementasi Kurikulum 2013 Revisi Kegiatan Inti diperoleh rerata (Mean) hasil analisis menggunakan perangkat lunak SPSS (Statistical Package for the Social Sciences) 17.0 for windows sebesar 44.2459 terletak pada kelas interval $>36$. Merujuk pada kriteria kecenderungan persepsi siswa maka dapat dijelaskan bahwa sebanyak 4 siswa memiliki persepsi bahwa pelaksanaan Kurikulum 2013 Revisi tidak terlaksana karena masih sama dengan sebelumnya. Selanjutnya sebanyak 5 siswa $(2,05 \%)$ memiliki persepsi bahwa pelaksanaan Kurikulum 2013 Revisi Terlaksana Kurang Baik, sebanyak 13 siswa (5,33\%) memiliki persepsi bahwa pelaksanaan Kurikulum 2013 Revisi Terlaksana cukup Baik, sebanyak 13 siswa $(19,00 \%)$ memiliki persepsi bahwa pelaksanaan kurikulum 2013 revisi terlaksana baik dan sebanyak 222 siswa $(90,98 \%)$ memiliki persepsi bahwa pelaksanaan kurikulum 2013 revisi terlaksana sangat baik.

Pada hasil analisis ditemukan nilai rerata (mean) sebesar 44,25 ada di rentangan >36 maka dikatakan bahwa kecenderungan kegiatan pembelajaran di bagian inti oleh siswa dipersepsikan sangat baik.

Persepsi siswa terhadap kegiatan penutup dapat dijelaskan sebagai berikut. Data hasil penelitian menunjukkan bahwa Persepsi Siswa SMK terhadap Implementasi Kurikulum 2013 edisi revisi Kegiatan Penutup diperoleh rerata (mean) sebesar 12,62 terletak pada kelas interval $>11$.

Merujuk pada kriteria kecenderungan persepsi siswa maka dapat dijelaskan 
bahwa sebanyak 3 siswa memiliki persepsi bahwa pelaksanaan Kurikulum 2013 Revisi tidak terlaksana karena masih sama dengan sebelumnya. Selanjutnya sebanyak 12 siswa (5\%) memiliki persepsi bahwa pelaksanaan K13 edisi revisi di kegiatan penutup terlaksana $\mathrm{Ku}-$ rang Baik, sebanyak 19 siswa $(8 \%)$ memiliki persepsi bahwa pelaksanaan K13 edisi revisi kegiatan penutup terlaksana baik dan sebanyak 210 siswa (86\%) memiliki persepsi bahwa pelaksanaan K13 edisi revisi kegiatan penutup terlaksana Sangat Baik. Pada hasil analisis ditemukan nilai rerata (mean) sebesar 12,623 ada di rentangan >11 maka dikatakan bahwa kecenderungan kegiatan pembelajaran di bagian penutup oleh siswa dipersepsikan baik.

Perencanaan, pelaksanaan, dan evaluasi pembelajaran dalam implementasi kurikulum 2013 revisi dapat dijelaskan sebagai berikut. Berdasarkan Tabel 1 analisis deskriptif menunjukkan bahwa persepsi guru di sub variabel perencanaan pembelajaran menyatakan bahwa keseluruhan implementasi kurikulum 2013 revisi sepenuhnya terlaksana. Hal ini ditunjukkan bahwa kriteria sepenuhnya terlaksana memiliki frekuensi yang banyak dimana sebanyak 1 orang memiliki persepsi bahwa implementasi belum terlaksana kemudian 7 orang $(41,00 \%)$ memiliki persepsi bahwa perencanaan pembelajaran sebagian besar sudah terlaksana sedangkan sebanyak 9 orang $(53,00 \%)$ memiliki penilai skor yang ada di masing-masing persepsi guru yang masuk dalam kriteria yang sama namun dengan rerata yang berbeda hal ini menunjukkan bahwa seorang guru jelas memiliki paradigma yang berbeda-beda mengenai pelaksanaan pembelajarannya.

Pada Tabel 2 analisis deskriptif menunjukkan bahwa persepsi guru pada sub variabel pelaksanaan pembelajaran menyatakan bahwa keseluruhan implementasi kurikulum 2013 revisi sepenuhnya terlaksana. Deskriptif persentase menunjukkan bahwa sebanyak 1 orang $(6,00 \%)$

Tabel 1. Persepsi Guru terhadap Perencanaan Pembelajaran

\begin{tabular}{cccc}
\hline Rentang Skor & Frekuensi & Persentase & Kriteria \\
\hline $21-32$ & 1 & $6,00 \%$ & Belum Terlaksana \\
$33-44$ & 0 & $0,00 \%$ & Sebagian Kecil Terlaksana \\
$45-56$ & 7 & $41,00 \%$ & Sebagian Besar Terlaksana \\
$57-74$ & 9 & $53,00 \%$ & Sepenuhnya Terlaksana \\
\hline Jumlah & 17 & $100,00 \%$ & \\
\hline
\end{tabular}

Tabel 2. Persepsi Guru terhadap Pelaksanaan Pembelajaran

\begin{tabular}{cccc}
\hline Rentang Skor & Frekuensi & Persentase & Kriteria \\
\hline $24-38$ & 1 & $6,00 \%$ & Belum Terlaksana \\
$39-53$ & 1 & $6,00 \%$ & Sebagian Kecil Terlaksana \\
$54-68$ & 4 & $24,00 \%$ & Sebagian Besar Terlaksana \\
$69-94$ & 11 & $65,00 \%$ & Sepenuhnya Terlaksana \\
\hline Jumlah & 17 & $100,00 \%$ & \\
\hline
\end{tabular}

Tabel 3. Persepsi Guru terhadap Evaluasi Pembelajaran

\begin{tabular}{cccc}
\hline Rentang Skor & Frekuensi & Persentase & Kriteria \\
\hline $6-8$ & 1 & $6,00 \%$ & Belum Terlaksana \\
$9-11$ & 1 & $6,00 \%$ & Sebagian Kecil Terlaksana \\
$12-14$ & 3 & $18,00 \%$ & Sebagian Besar Terlaksana \\
$15-23$ & 12 & $71,00 \%$ & Sepenuhnya Terlaksana \\
\hline Jumlah & 17 & $100,00 \%$ & \\
\hline
\end{tabular}


memiliki persepsi tentang implementasi belum terlaksana, sebanyak 1 orang $(6,00 \%)$ juga mengatakan bahwa sebagian kecil terlaksana kemudian 4 orang $(24,00 \%)$ memiliki persepsi bahwa perencanaan pembelajaran sebagian besar sudah terlaksana sedangkan sebanyak 11 orang $(65,00 \%)$ memiliki persepsi terlaksana sepenuhnya.

Sementara Tabel 3 analisis deskriptif menunjukkan bahwa persepsi guru pada sub variabel evaluasi pembelajaran menyatakan bahwa keseluruhan implementasi kurikulum 2013 revisi sepenuhnya terlaksana. Deskriptif persentase menunjukkan bahwa sebanyak 1 orang $(6,00 \%)$ memiliki persepsi tentang implementasi belum terlaksana, sebanyak 1 orang $(6,00 \%)$ juga mengatakan bahwa sebagian kecil terlaksana kemudian 3 orang $(18,00 \%)$ memiliki persepsi bahwa perencanaan pembelajaran sebagian besar sudah terlaksana sedangkan sebanyak 12 orang $(71,00 \%)$ memiliki persepsi terlaksana sepenuhnya.

\section{PEMBAHASAN}

Kemampuan guru dalam mengimplementasikan Kurikulum 2013 Revisi berpengaruh pada proses pembelajaran. Hal ini sesuai dengan penelitian Wardhani (2015) menerangkan "Dari hasil penelitian terkait dengan proses pembelajaran, guru tidak mengalami kesulitan dalam mengembangkan RPP, guru mengalami kesulitan dalam proses penilaiannya. Dalam penerapan pendekatan saintifik tidak semua guru menerapkannya, terdapat guru yang mengalami kesulitan untuk penerapan pendekatan saintifik". Didukung dengan kerja sama yang baik oleh semua pihak yang terkait telah memberikan respon positif terhadap $\mathrm{Ku}-$ rikulum 2013 dengan dikeluarkannya Kurikulum 2013 Revisi. Hal ini berdasarkan hasil penelitian yang diperoleh dari Sari (2017) menyatakan bahwa, "Pema- haman guru ekonomi tentang implementasi pembelajaran ekonomi berbasis Kurikulum 2013 Revisi di SMA Negeri 2 Malang dan SMA Negeri 3 Malang sudah cukup baik. Guru Ekonomi telah mampu menjelaskan tentang perencanaan, pelaksanaan, dan penilaian/evaluasi proses dan hasil pembelajaran berdasarkan Kurikulum 2013 Revisi”.

Hasil penelitian ini menunjukkan bahwa proses belajar mengajar yang ada di SMK Kota Blitar sudah terlaksana dengan baik karena guru dalam melaksanakan tugasnya juga sudah memenuhi tujuan serta visi misi dari Kurikulum 2013 Revisi itu sendiri. Dalam proses belajar, guru bertugas memberikan pembelajaran terhadap siswa sehingga tujuan pembelajaran dapat tercapai. Salah satu upaya yang paling praktis dan realitas dalam meningkatkan kualitas proses dan hasil belajar para siswa. Sebagai indikator kualitas pendidikan adalah perbaikan dan penyempurnaan sistem pembelajaran. Upaya tesebut diarahkan kepada kualitas pembelajaran sebagai suatu proses yang diharapkan dapat menghasilkan kualitas hasil belajar yang optimal.

Ketika hasil belajar siswa dapat optimal maka akan tercipta sebuah persepsi positif yang muncul dalam diri siswa karena segala persepsi akan bergantung pada apa yang sudah dilaksanakan oleh guru itu sendiri. Hal ini juga disebabkan bahwa Komponen utama dalam sistem pendidikan adalah peserta didik, guru dan kurikulum. Dalam proses belajar mengajar ketiga komponen tersebut mempunyai hubungan yang tak terpisahkan satu dengan yang lainnya. Tanpa kehadiran salah satu dari komponen tersebut, proses interaksi edukatif tidak akan berjalan dan tujuan pendidikan tidak akan tercapai. Sebagai contoh mengutip dari hasil penelitian berdasarkan Kurikulum 2013 di SMK seMalang Raya yang diperoleh dari Gunawan dan Mukhadis (2017) 
menyimpulkan bahwa, Siswa SMK kurang tertarik pada pembelajaran matematika dengan pendekatan saintifik ditinjau dari aspek persiapan pembelajaran dan pelaksanaan pembelajaran. Hal ini dikarenakan di dalam aspek persiapan pembelajaran masih ada indikator yang kurang efektif yaitu pencapaian tujuan pembelajaran dan penyusunan RPP selebihnya ditinjau pada aspek pelaksanaan pembelajaran juga kurang efektif. Maka kasus tersebut perlu tindak lanjut dan tanggapan yang tepat kepada semua pihak terkait agar proses interaksi edukatif dapat berjalan sesuai harapan dan tujuan pendidikan dapat tercapai.

Keempat aspek dalam sistem pembelajaran, yaitu kurikulum, perencanaan pembelajaran, pelaksanaan pembelajaran, dan evaluasi/hasil pembelajaran merupakan suatu kesatuan yang utuh dan saling mempengaruhi. Maka dapat disimpulkan bahwa dengan perencanaan yang telah dibuat, maka guru ketika melaksanakan proses pembelajaran secara umum akan mengikuti langkah-langkah atau prosedur dan aktivitas pembelajaran disesuaikan dengan rencana yang telah dibuat sebelumnya. Apabila setiap guru ketika mengajar selalu membuat rencana pelaksanaan pembelajaran dan secara disiplin patuh terhadap perencanaan yang telah dibuat ketika mengajarnya, maka tidak akan terjadi kesenjangan antara perencanaan pembelajaran dengan pelaksanaan pembelajaran. Serta Implementasi Kurikulum 2013 Revisi dapat dipastikan berjalan sesuai dengan harapan.

\section{SIMPULAN DAN SARAN}

Berdasarkan pembahasan hasil penelitian terhadap Implementasi Kurikulum 2013 Revisi pada mata pelajaran Teknologi Dasar Otomotif kelas X TKR di SMK dapat disimpulkan sebagai berikut. (1) Persepsi guru terhadap Implementasi Kurikulum 2013 Revisi pada mata pel- ajaran Teknologi Dasar Otomotif kelas X TKR di SMK berada pada taraf terlaksana dengan baik. (2) Persepsi siswa terhadap Implementasi Kurikulum 2013 Revisi pada mata pelajaran Teknologi Dasar Otomotif kelas X TKR di SMK peneliti melakukan analaisis pada 3 poin utama yaitu kegiatan pendahuluan, kegiatan inti dan kegiatan penutup. Data hasil penelitian menunjukkan bahwa persepsi siswa SMK terhadap implementasi kurikulum 2013 revisi pada kegiatan pendahuluan dipersepsikan terlaksana Baik. Selanjutnya pada kuisioner kegiatan inti dipersepsikan sangat baik. Sedangkan pada kegiatan penutup dipersepsikan baik. (3) Perencanaan, pelaksanaan, dan evaluasi pembelajaran dalam Implementasi Kurikulum 2013 Revisi pada mata pelajaran Teknologi Dasar Otomotif Kelas X TKR di SMK berdasarkan analisis di sub bab perencanaan pembelajaran menunjukkan bahwa persepsi guru di sub variabel perencanaan pembelajaran menyatakan bahwa keseluruhan implementasi kurikulum 2013 revisi sepenuhnya terlaksana.

Berdasarkan kesimpulan dari pembahasan yang telah dideskripsikan maka diajukan beberapa saran sebagai berikut. (1) Guru memiliki persepsi yang baik terhadap Kurikulum 2013 namun perlu dipertahankan dan ditingkatkan supaya kedepannya dapat meningkatkan kualitas proses belajar mengajar. Selanjutnya guru diharapkan untuk meningkatkan profesionalitas dan bijak dalam menanggapi perubahan sehingga segala sesuatu dapat dipersiapkan dengan baik serta memiliki dukungan sumber belajar yang memadai. Kepala sekolah hendaknya melakukan monitoring berkala dan meningkatkan kemampuan guru terhadap proses pembelajaran dalam mengimplementasikan Kurikulum 2013. Waka kurikulum perlu mengadakan pelatihan berupa penataran di sekolah khususnya tentang Kurikulum 2013 agar guru benar-benar me- 
mahami Implementasi Kurikulum 2013 dengan baik. (2) Respon dari peserta didik dalam pelaksanaan pembelajaran terhadap Implementasi Kurikulum 2013 sudah baik tetapi perlu ditingkatkan. Peserta didik diharapkan agar belajar secara mandiri serta aktif dan kreatif agar proses belajar mengajar berjalan dengan lancar. (3) Melalui Musyawarah Guru Mata Pelajaran (MGMP) dalam sosialisasinya diharapkan mampu meningkatkan kompetensi guru terhadap Kurikulum 2013 pada proses pembelajaran yang meliputi perencanaan, pelaksanaan, dan evaluasi terutama ditekankan pada perencanaan pembelajaran berupa pengembangan RPP. Secara praktis hasil penelitian ini diharapkan mampu memaparkan kondisi Kurikulum 2013 dalam bentuk persepsi guru dan siswa serta dapat menjadi acuan untuk dilakukannya penelitian lanjutan terhadap Implementasi Kurikulum 2013 dengan menambah atau mengembangkan variabel lain yang belum termasuk dalam penelitian ini supaya pada praktiknya dapat meminimalisir kesenjangan pada proses pembelajaran.

\section{DAFTAR RUJUKAN}

Amanto, H., Mukhadis, A., \& Mardji. 2013. Pemetaan Kompetensi, Sikap, Tanggung Jawab, dan Jumlah Jam Guru Bersertifikat Pendidik dalam Mengelola Pembelajaran di SMK. Teknologi dan Kejuruan, 36(1):1-8.

Baswedan, A. Juni 2016. Dari Mas Menteri. Media Komunikasi dan Inspirasi: Jendela: Pendidikan dan kebudayaan, III(3):4-5.

Dirjen Dikdasmen RI. 2013. SK Tahun 2013, tentang Penetapan Satuan Pendidikan Pelaksana Kurikulum 2013 Revisi. Jakarta: Ditjen Dikdasmen.

Gunawan \& Mukhadis, A. 2017. Keefektivan Guru, Ketrarikan Siswa pada Pembelajaran Matematika de- ngan Pendekatan Saintifik di Sekolah Menengah Kejuruan. Teknologi dan Kejuruan, 40(1): 41-50.

Leonokto, I. 2016. Persepsi Guru dan Siswa terhadap Implementasi Kurikulum 2013 dalam Pembelajaran Sejarah (Studi Kasus di SMA Negeri 1 Depok Yogyakarta). Skripsi tidak diterbitkan. Yogyakarta: Universitas Sanata Dharma.

Molikavia, R., Putro, S.C., \& Widiyaningtyas, T. 2015. Hubungan Kecakapan Sosial dan Kemampuan Logika dengan Keberhasilan Dalam Prakerin Siswa SMK. Teknologi dan Kejuruan, 38(1): 15-24.

Mukhadis, A. 2016. Metodologi Penelitian Kuantitatif: Bidang Pendidikan dan Contoh Apikasinya. Malang: Aditya Media Publishing.

Mukhadis, A. 2017. Evaluasi Program Pembelajaran Bidang Teknologi: Terminologi, Prosedur Pengembangan Program dan Instrumen. Malang: Media Nusa Creative.

Pemerintah RI. 2013. Peraturan Pemerintah RI No. 23 Tahun 2013, tentang kurikulum 2013. Jakarta: Mendiknas.

Roche, S. 2017. Learning For Life, For Work, and For Its Own Sake: The Value (and Values) of Lifelong Learning. International Review of Education. 63(5): 623-629. (Online), dalam Spinger (https:// link.springer. com/article/10.1007/s11159-0179666-x/fulltext.html, diakses 28 September 2017).

Sari, D.I. 2017. Implementasi Pembelajaran Ekonomi Berbasis Kurikulum 2013 Revisi di SMA Negeri 2 Malang dan SMA Negeri $3 \mathrm{Ma}$ lang. Skripsi tidak diterbitkan. Malang: Universitas Negeri Malang.

Sasmito, A.P., Kustono, D., \& Patmanthara, S. 2015. Kesiapan Memasuki Dunia Usaha/Dunia Industri (DU/ DI) Siswa Paket Keahlian Rekayasa 
Perangkat Lunak SMK. Teknologi dan Kejuruan, 38(1): 25-40.

Tuwoso. 2013. Urgensi Penerapan Pendidikan Karakter pada Sekolah Menengah Kejuruan. Teknologi dan $\mathrm{Ke}$ juruan, 36(1): 97-106.

Undang-undang RI No. 20. Tahun 2003, tentang Sistem Pendidikan Nasional. Jakarta: Mendiknas.

Untari, R. S., Mukhadis, A., \& Waras. 2015. Kesiapan Guru SMK Program Keahlian Teknik Komputer dan Informatika dalam Pelaksanaan Kurikulum 2013. Teknologi dan Kejuruan, 38(1): 1-14.
Wardhani, A.S. 2015. Dukungan Kepala Sekolah, Guru, dan Siswa terhadap Pelaksanaan Kurikulum 2013 di SMKN 1 Trenggalek. Skripsi tidak diterbitkan. Malang: Universitas Negeri Malang.

Waybin, E.F. 2014. Implementasi Kurikulum 2013 dalam Proses Pembelajaran di SMK Negeri 3 Yogyakarta. Skripsi tidak diterbitkan. Yogyakarta: Universias Negeri Yogyakarta. 